\title{
Penyuluhan Tentang Peremajaan Kelapa Sawit Dan Legalitas Lahan Di Kecamatan Kempas Kabupaten Indragiri Hilir
}

\author{
Mulono Apriyanto ${ }^{*}$, KMS. Novyar Satriawan Fikri ${ }^{2}$, Vivi Arfiani Siregar ${ }^{2}$, Jamri $^{2}$, Ali Azhar ${ }^{2}$ \\ ${ }^{1}$ Fakultas Pertanian, Universitas Islam Indragiri, Riau, Indonesia \\ ${ }^{2}$ Fakultas Hukum, Universitas Islam Indragiri, Riau, Indonesia \\ Email: 1" mulonoapriyanto71@gmail.com, ${ }^{2}$ novyarsatriawan3@gmail.com, ${ }^{2}$ viviarsh1@gmail.com, ${ }^{2}$ jamri@gmail.com, \\ ${ }^{2}$ sahabat.aliazhar@gmail.com \\ (*: coressponding author)
}

\begin{abstract}
Abstrak- Tujuan dan target khusus dari kegiatan pengabdian masyarakat ini adalah untuk memberikan penyuluhan tentang peremajaan kelapa sawit dan legalitas lahan petani sehingga terjadi perubahan pengetahuan, pemahaman dan ketrampilan petani yang tergabung dalam kelompok tani dalam upaya untuk mau melakukan peremajaan tanaman kelapa sawit dan untuk memberikan pemahaman pentingnya legalitas lahan petani sebagai bagian tak terlepaskan dari struktur syarat guna mendapatkan bantuan dana untuk melakukan peremajaan tanaman kelapa sawit. Metode yang digunakan yaitu metode penyuluhan, sosialisasi, demonstrasi dan pendampingan pada saat kegiatan penyuluhan berlangsung. Metode penyuluhan memberikan penyuluhan dan melakukan pelatihan setelah dilakukan penyuluhan. Metode demonstrasi dilakukan pada saat penyampaian materi. Petani langsung memprakekkan cara melakukan peremajaan tanaman kelapa sawit, setelah itu diberikan penyuluhan tentang cara dan fungsi legalitas lahan petani serta kelembagaan kelompok tani dalam rangka mendapatkan dana secara berkelompok. Metode pendampingan bertujuan untuk memantau perkembangan setelah dilakukan penyuluhan kepada petani dengan melibatkan agent perubahan yaitu tokoh masyarakat, pemuka adat, pihak pemerintah desa dan pihak lembaga perbankan. Secara umum pelaksanaan pengabdian di desa kerta jaya dan rumbai jaya Kecamatan Kempas Kabupaten Indragiri Hilir dapat berjalan dengan baik dan lancar.
\end{abstract}

Kata Kunci: peremajaan tanaman kelapa sawit, legalitas lahan petani, penyuluhan, media penyuluhan

\begin{abstract}
The specific objectives and targets of these community service activities are to provide counseling on the rejuvenation of oil palm and the legality of farmers' land so that there is a change in the knowledge, understanding and skills of farmers who are members of farmer groups in an effort to want to rejuvenate oil palm plants and to provide an understanding of the importance of legality Farmer's land as an inseparable part of the structure of the requirements in order to get financial assistance to rejuvenate oil palm plants. The methods used are counseling, outreach, demonstration and assistance when the extension activities take place. Counseling methods provide counseling and conduct training after counseling. The demonstration method is carried out at the time of delivery of material. Farmers immediately practiced how to rejuvenate oil palm plants, after that they were given counseling about the ways and functions of farmers' land legality and farmer group institutions in order to get funds in groups. The assistance method aims to monitor developments after counseling to farmers by involving agents of change, namely community leaders, traditional leaders, the village government and banking institutions. In general, the implementation of community service in Kerta Jaya and Tassel Jaya villages, Kempas Subdistrict, Indragiri Hilir Regency can run well and well..
\end{abstract}

Keywords: oil palm plant rejuvenation, the legality of farmers' land, extension, extension media

\section{PENDAHULUAN}

Kelapa sawit mulai merupakan komoditi perkebunan yang memiliki banyak manfaat dibidang industri (Irianto dan Mulono Apriyanto 2012). Produki minyk awit (CPO) di dalam negeri banyak diserap oleh industri pangan. Manfaat kelapa sawit diantaranya sebagai bahan baku untuk industri pangan (minyak goreng) dan industri untuk non pangan (kosmetik dan farmasi) serta sebagai salah satu bahan penghasil biodesel (Irianto dan Apriyanto 2012).

Perkebunan kelapa sawit di Indonesia menurut status pengusahaannya diusahakan oleh perkebunan rakyat (smallholders) sebanyak 42,3 persen. Berdasarkan data Direktorat Jenderal Perkebunan (DITJENBUN), perkebunan rakyat mengalami peningkatan luas areal perkebunan setiap tahunnya (Wiratmadja dkk., 2017). Luas areal perkebunan rakyat akan terus meningkat menjadi pemilik pangsa kepengusahaan kelapa sawit terbesar di Indonesia (Sibarani, dkk., 2015). Perkebunan rakyat diusahakan oleh petani pola plasma dan petani pola swadaya. Perusahaan inti membina dan mengembangkan perkebunan plasma penyediaan sarana produksi, pemberian bimbingan teknis manajemen usaha, penguasaan dan peningkatan teknologi yang diperlukan bagi peningkatan efisiensi dan produktifitas usaha (UU nomor 9 tahun 1995).

Petani swadaya adalah petani yang dengan inisiatif dan biaya sendiri membuka dan mengelola lahan, tidak terkait dengan perusahaan tertentu, konkret, dan benar-benar merupakan permasalahan prioritas masyarakat mitra (Zeweld dkk. 2017).

Petani swadaya murni sama sekali belum memiliki kelembagaan KUD dan kelompok tani, yang disebabkan oleh lemahnya pembinaan oleh instansi, akibat tidak terdatanya pekebun kelapa sawit murni (Puspa., 2018).

Petani rakyat sebagai pelaku rantai pasok hulu memiliki peranan penting dalam menciptakan sistem rantai pasok yang terintegrasi dalam mengatasi isu berkelanjutan dan meningkatkan produktivitas (Nugraheni dan Pangaribuan 2008). Industri kelapa sawit Indonesia dalam dasa warsa sekarang dihadapkan dengan isu keberlanjutan yang merupankan tantangan bagi seluruh pelaku rantai pasok, khususnya petani rakyat sebagai produsen. Menurut Palm Oil Agribusiness 


\section{JPM: Jurnal Pengabdian Masyarakat}

Vol 1, No 1, Juli 2020, Hal 1-6

ISSN XXXX-XXXX (Media Online)

Strategic Policy Institute (PASPI), sejumlah Lembaga melakukan kampanye negatif terhadap industri minyak sawit Indonesia (Fahamsyah 2018).

Kampanye tersebut mempengaruhi opini semua rantai pasok mulai dari konsumen, produsen, industri dan kelembagaan pendukung, hingga pemerintah (Apriyanto dkk., 2020). Isu keberlanjutan ini dapat menghambat akses pasar komoditas kelapa sawit di pasar internasional.

Di dalam P\&C RSPO dan ISPO terdapat teknik budidaya dan pengelolaan kelapa sawit yang baik (Good Agriculture Practices/GAP), yang dapat mendukung pembangunan kelapa sawit berkelanjutan secara ekonomi, sosial dan lingkungan (Ariyanti dkk., 2019).Pembukaan lahan tanpa bakar, menggunakan pupuk organik, pengendalian organisme pengganggu tanaman (OPT) secara organik, menggunakan bibit bersertifikat, mengikuti kelompok tani, dan menggunakan lahan bebas konflik merupakan bagian dari praktik-praktik keberlanjutan pada GAP (Dharmawan dkk., 2019). Sertifikasi RSPO (Roundtable Sustainable Palm Oil) dan ISPO (Indonesian Sustainable Palm Oil) merupakan standar dan parameter global berkelanjutan untuk produk-produk yang dihasilkan dari kelapa sawit. RSPO dan ISPO memiliki Principles \& Criteria (P\&C) yang berfokus pada hukum, ekonomi, lingkungan, kebutuhan sosial untuk produksi kelapa sawit berkelanjutan.

Niat petani terhadap keberlanjutan dapat diprediksi dengan menggunakan TPB karena kemampuannya dalam menangani perilaku kompleks yang menggambarkan mekanisme yang membuat orang mendukung praktik-praktik berkelanjutan (Nurfathiyah dan Rendra 2013). Di Indonesia kelapa sawit

merupakan salah satu komoditi dominan dari sektor perkebunan. Pada tahun 2012, luas areal perkebunan kelapa sawit mencapai 9,27 juta hektar dan produksi minyak sawit mencapai 23,633 juta ton per tahun Sebagian besar areal perkebunan kelapa sawit tersebut berada di Sumatra, khususnya Provinsi Riau sedangkan kontribusi perkebunan rakyat mencapai 45\% (Hutasoit dkk., 2015). Untuk meningkatkan produksi kelapa sawit yang berkelanjutan, maka para pelaku usahatani kelapa sawit juga harus memperhatikan umur ekonomis kelapa sawit. Apabila perkebunan kelapa sawit telah mencapai umur ekonomis sekitar 25 tahun maka petani perlu melakukan peremajaan atau replanting (Apriyanto dkk., 2020), (Nurfathiyah dan Rendra, 2013).

Peremajaan merupakan pergantian tanaman tua yang tidak ekonomis lagi dengan tanaman baru. Beberapa hal yang perlu diperhatikan dalam peremajaan kelapa sawit antara lain kapan replanting dilakukan, apa kriteria tanaman akan direplanting, apa jenis bibit yang akan digunakan, dan sumber dana untuk membiayai replanting. Menurut Apriyanto dkk., (2020), bahwa petani kelapa sawit umumnya berumur diatas 20 tahun atau kurang tetapi produktivitas rendah atau dibawah 13 ton TBS/ha/tahun yang mengakibatkan keuntungan yang diperoleh oleh petani menurun. Kondisi ini akan berimplikasi pada menurunnya pendapatan petani sementara untuk melakukan replanting dibutuhkan dana yang relatif besar bagi petani.

Sebagai satu daerah perkembangan kelapa sawit di Provinsi Riau Kecamatan Kempas adalah Kecamatan pertama yang mulai membudidayakan kelapa sawit di Kabupaten Indragiri Hilir, yakni dimulai pada Tahun 1998/1999. Kecamatan Kempas memiliki kategori areal perkebunan kelapa sawit petano swadaya..

\section{METODE PELAKSANAAN}

Menurut hasil penelitian Hutasoit dkk., (2015), tindakan peremajaan kelapa sawit oleh petani sangat dipengaruhi oleh persepsi yang berdasarkan pada pengetahuan dan pengalaman petani tentang pentingnya peremajaan dalam meningkatkan produksi kelapa sawit. Hasil pengamatan tim pengabdian masyarakat saat melakukan observasi awal terlihat beberapa permasalahan yang ada dilokasi pengabdian adalah :

a. Kurangnya pengetahuan petani tentang pentingnya peremajaan kelapa sawit dan memilih benih kelapa sawit yang berkualitas, hal ini disebabkan karena keterbatasan informasi yang diperoleh petani dan penyuluh baik melalui penyuluhan atau pelatihan

b. Keterbatasan akses permodalan untuk melakukan peremajaan kelapa sawit, hal ini disebabkan karena pengetahuan petani yang masih kurang tentang peranan kelembagaan terutama kelembagaan kelompok tani dalam mendapatkan akses permodalan.

c. Kurangnya pengetahuan petani tetang legalitas dan proses pengesahan legalitas lahan sebagai hak milik.

d. Keterbatasan media penyuluhan baik media cetak maupun media elektronik yang dapat digunakan oleh penyuluh dalam kegiatan penyuluhan kepada petani tentang peremajaan kelapa sawit dan peranan kelembagaan petani.

Penggunaan ketiga solusi diatas akan dilakukan serangkaian langkah manajemen proses yang terdiri dari sosialisasi, penyusunan proposal, survey dan analisis kebutuhan informasi, penyusunan materi penyuluhan, pelaksanaan kegiatan penyuluhan tentang peremajaan kelapa sawit, pelaksanaan kegiatan penyuluhan tentang kelembagaan petani, pelaksanaan kegiatan penyuluhan melalui pendekatan media, monitoring dan evaluasi, penyusunan laporan penelitian, penggandaan dan penyerahan laporan pengabdian. Fase persiapan terdiri dari penyusunan proposal, survey dan analisis kebutuhan informasi (Apriyanto, 2019).

Survey dilakukan guna analisis kebutuhan informasi yang dibutuhkan dalam menghimpun informasi dasar yang dibutuhkan dalam analisis masalah serta kebutuhan petani. Informasi yang didapatkan berupa data jumlah petani, kelompok tani,keaktifan petani dalam kelompok, luas kebun dan kondisi terkini pelaksanaan peremajaan kelapa sawit. 


\section{JPM: Jurnal Pengabdian Masyarakat}

Vol 1, No 1, Juli 2020, Hal 1-6

ISSN XXXX-XXXX (Media Online)

Penyususnan materi penyuluhan didasari oleh informasi yang telah didapatkan sebelumnya. Analisis permasalahan merupakan salah satu pertimbangan mendasar dalam menyusun materi. Fase pelaksanaan berupa kegiatan penyuluhan tentang peremajaan kelapa sawit (Year dkk., 2017). Kegiatan ini meliputi sosialisasi tentang persiapan lahan serta aspek budidaya kelapa sawit yang disesuaikan dengan rekomendasi pemerintah. Pelaksanaan penyuluhan tentang kelembagaan petani berupa kegiatan penyuluhan tentang pengaktifan kembali kelompok tani sebagai sarana dalam mengakses modal.

Fase monitoring dan evaluasi yaitu kegiatan perekaman terhadap persiapan, proses dan hasil kegiatan sosialisasi penyuluhan. Monitoring persiapan akan memperhatikan kelengkapan aspek yang dipersiapkan dalam proses kegiatan penyuluhan (Apriyanto, 2019). Monitoring proses memperhatikan penggunaan liftlet dalam membantu proses penyuluhan. Selain itu memberikan pengarahan dan koordinasi apabila ada respon Monitoring hasil akan memperhatikan respon peserta penyuluhan yang merupakan indikasi keinginan petani dalam melaksanakan peremajaan yang sesuai dengan anjuran pemerintah dari peserta penyuluhan yang diikuti oleh petani yang dalam kelompoktani.

Fase terakhir berupa kegiatan penyusunan laporan pengabdian serta pengadaan dan penyerahan laporan pengabdian. Fase terakhir berupa dokumentasi kegiatan dan rincian kegiatan yang dilaksanakan disesuaikan dengan item kegiatan yang dilaksanakan.

Tabel 1. Rencana Kegiatan Pengabdian Masyarakat (PPM)

\begin{tabular}{lll}
\hline No & Jenis Kegiatan & Penanggung Jawab Kegiatan \\
\hline 1 & Sosialisasi & Tim PPM \\
2 & Pelaksanaan Penyuluhan & Tim PPM \\
3 & Kelembagaan petani & Tim PPM \\
4 & Pelaksanaan monitoring & Tim PPM \\
5 & Pelaksanaan pendampingan & Tim PPM \\
\hline
\end{tabular}

\section{HASIL DAN PEMBAHASAN}

Adapun hasil dari pelaksanaan penyuluhan tentang peremajaan kelapa sawit dan legalitas lahan di Kecamatan Kempas Kabupaten Indragiri Hilir, sebagai berikut:

a. Pelaksanaan Kegiatan

Peserta kegiatan pengabdian masyarakat diikuti oleh petani di desa rumbai jaya dan kerta jaya. Pelaksanaan kegiatan dimulai dari survey lapangan untuk menganalisis permasalahan dan analisis kebutuhan informasi yang sangat diperlukan petani di lokasi pengabdian dan mencari solusi permasalahan, pengumpulan data sekunder dan primer.

Dari hasil survey dan wawancara dengan beberapa anggota kelompok tani diperoleh informasi bahwa permasalahan yang penting untuk segera diatasi adalah rata-rata umur tanaman kelapa sawit di lokasi pengabdian telah mencapai umur diatas 25 tahun sehingga perlu segera dilakukan peremajaan kelapa sawit dan perlunya mengaktifkan kembali kelompok tani karena syarat untuk mendapatkan bantuan dana untuk peremajaan dari pemerintah adalah petani harus berkelompok.

Kegiatan ini melibatkan kelompok tani, PPL dan tokoh masyarakat. Bagian ini merupakan bagian utama artikel hasil pengabdian dan biasanya merupakan bagian terpanjang dari suatu artikel. Kegiatan penyuluhan, monitoring dan evaluasi merupakan kegiatan akhir dari kegiatan penyuluhan yang dilakukan oleh tim pengabdian masyarakat fakultas pertanian dan fakultas hukum Universitas Islam Indragiri, pada gambar 1.

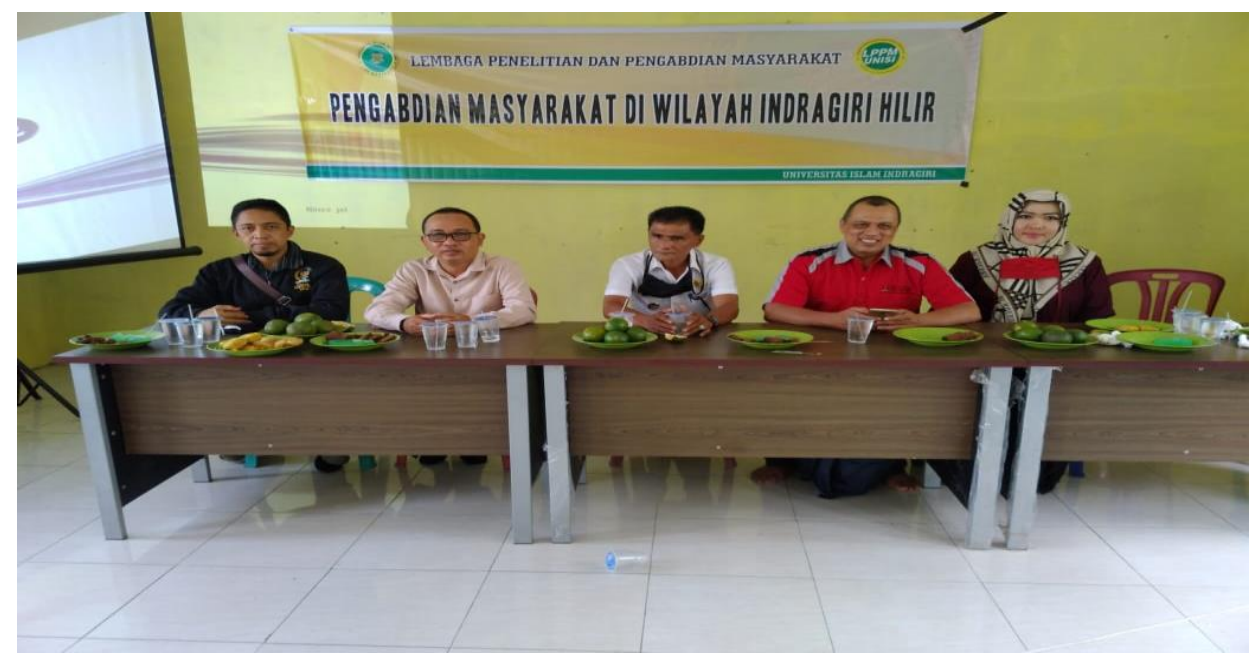

Gambar 1. Tim Pendamping dan Sosialisasi PPM

Kegiatan selanjutnya pelaksanaan kegiatan penyuluhan tentang peremajaan kelapa sawit yang dilaksanakan oleh tim pengabdian melibatkan kelompok tani katu dan paria. 


\section{JPM: Jurnal Pengabdian Masyarakat}

Vol 1, No 1, Juli 2020, Hal 1-6

ISSN XXXX-XXXX (Media Online)

Kegiatan ketiga yaitu pelaksanaan kegiatan penyuluhan tentang kelembagaan petani dengan memberikan penyuluhan secara interaktif membahas tentang pentingnya mengaktifkan kelompok tani sebagai wahana belajar, diskusi dan akese informasi untuk mendapatkan bantuan dana. Kegiatan keempat melakukan kegiatan penyuluhan dengan menggunakan media cetak yaitu leflet yang berisikan tentang sistem peremajaan kelapa sawit untuk kebun rakyat dan kelembagaan petani. Kegiatan monitoring dilakukan dengan melakukan diskusi dan wawancara tentang kegiatan usahatani kelapa sawit, kendala-kendala petani dalam melakukan peremajaan kelapa sawit dan kendala kendala dalam mengaktifkan kelompok tani.

Kegiatan evaluasi dilakukan terhadap keberhasilan kegiatan yang dimulai dari taanggapan PPL terhadap materi yang disampaikan oleh tim pelaksana kegiatan penyuluhan berupa ceramah, demonstrasi, diskusi dan tanya jawab. Penyediaan pelayanan komunikasi dan informasi melalui telepon, wa dan email digunakan untuk mengkoordinir petani dengan cara menghubungkan petani dengan pemberi dana yaitu pemerintah melalui BPDPKS (Badan Pengelola Dana Perkebunan Kelapa Sawit).

b. Efek penyuluhan peremajaan kelapa sawit rakyat dan kelembagaan di Kecamatan Kempas

Kegiatan penyuluhan merupakan kegiatan pembelajaran antara petani dengan pemberi materi penyuluhan. Tim bertindak sebagai sumber yang menyampaikan pesan kepada petani sedangkan petani bertindak sebagai penerima pesan (Nurfathiyah and Rendra 2013). Fungsi penyuluhan adalah terjadi proses komunikasi yang bersifat timbal balik (feed back communication) sehingga tercapai kesamaan makna (Mutual Understanding) antara petani dengan tim pengabdian. Petani pada suatu waktu dapat bertindak sebagai sumber informasi jika petani memiliki informasi dan pengalaman sehingga proses pertukaran informasi dapat meningkatkan pengetahuan, sikap dan ketrampilan petani menjadi tahu dan mau menerapkan inovasi yang diberikan (Anonim, 2020). Hal ini memungkinkan karena terjadi proses diskusi tanya jawab antara tim pengabdian dengan petani.

Kegiatan penyuluhanyang dilakukan melalui demonstrasi dapat memaparkan secara rinci dan jelas bagaimana sebaiknya melakukan peremajaan kelapa sawit dengan memberikan pemaparan keuntungan dan kerugian dari tentang teknik peremajaan kelapa sawit yaitu sistem penumbangan serempak, teknik underplanting, teknik tumpang sari (intercropping) dan sistem peremajaan bertahap. Kegiatan penyuluhan dengan metode diskusi dan tanya jawab serta bantuan media cetak berupa leflet dapat mempercepat proses transformasi dari sumber kepada petani.

Permasalahan yang dihadapi oleh petani adalah (Puspa 2018): (1) Kurangnya pengetahuan petani tentang pentingnya peremajaan kelapa sawit, legalitas lahan, memilih benih kelapa sawit yang berkualitas. Keterbatasan informasi yang diperoleh petani dan penyuluh baik melalui penyuluhan atau pelatihan, (2) Keterbatasan akses permodalan untuk melakukan peremajaan kelapa sawit, hal ini disebabkan karena pengetahuan petani yang masih kurang tentang peranan kelembagaan terutama kelembagaan kelompok tani dalam mendapatkan akses permodalan, (3) Keterbatasan media penyuluhan baik media cetak maupun media elektronik yang dapat digunakan oleh penyuluh dalam kegiatan penyuluhan kepada petani tentang peremajaan kelapa sawit dan peranan kelembagaan petani.

Metode pelaksanaan menggunakan metode penyuluhan, sosialisasi, demonstrasi, evaluasi dan monitoring. Metode penyuluhan dilakukan dengan memberikan penyuluhan kepada petani tentang bagaimana cara melakukan peremajaan kelapa sawit dan kelembagaan petani (Apriyanto Mulono dkk., 2017). Metode sosialisasi dilakukan dengan menggunakan media cetak, metode demonstrasi dengan melakukan praktek dan simulasi bagaimana melakukan peremajaan kelapa sawit dan mengaktifkan kembali kelompok tani dengan mengaktifkan keanggotaan kelompok dalam simluhtan. Kondisi benih yang digunakan untuk peremajaan sawit rakyat tersaji pada gambar 2 .

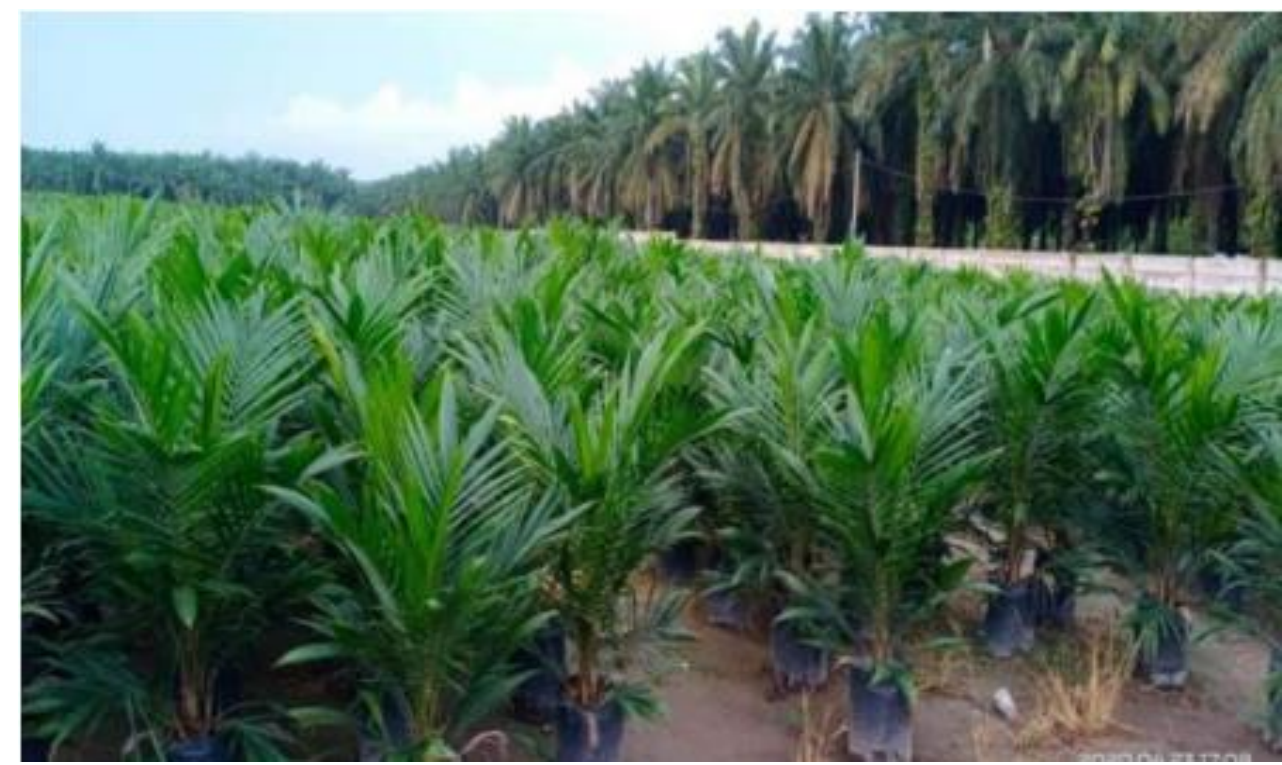

Gambar 2. Benih sawit yang akan ditanam 


\section{JPM: Jurnal Pengabdian Masyarakat}

Vol 1, No 1, Juli 2020, Hal 1-6

ISSN XXXX-XXXX (Media Online)

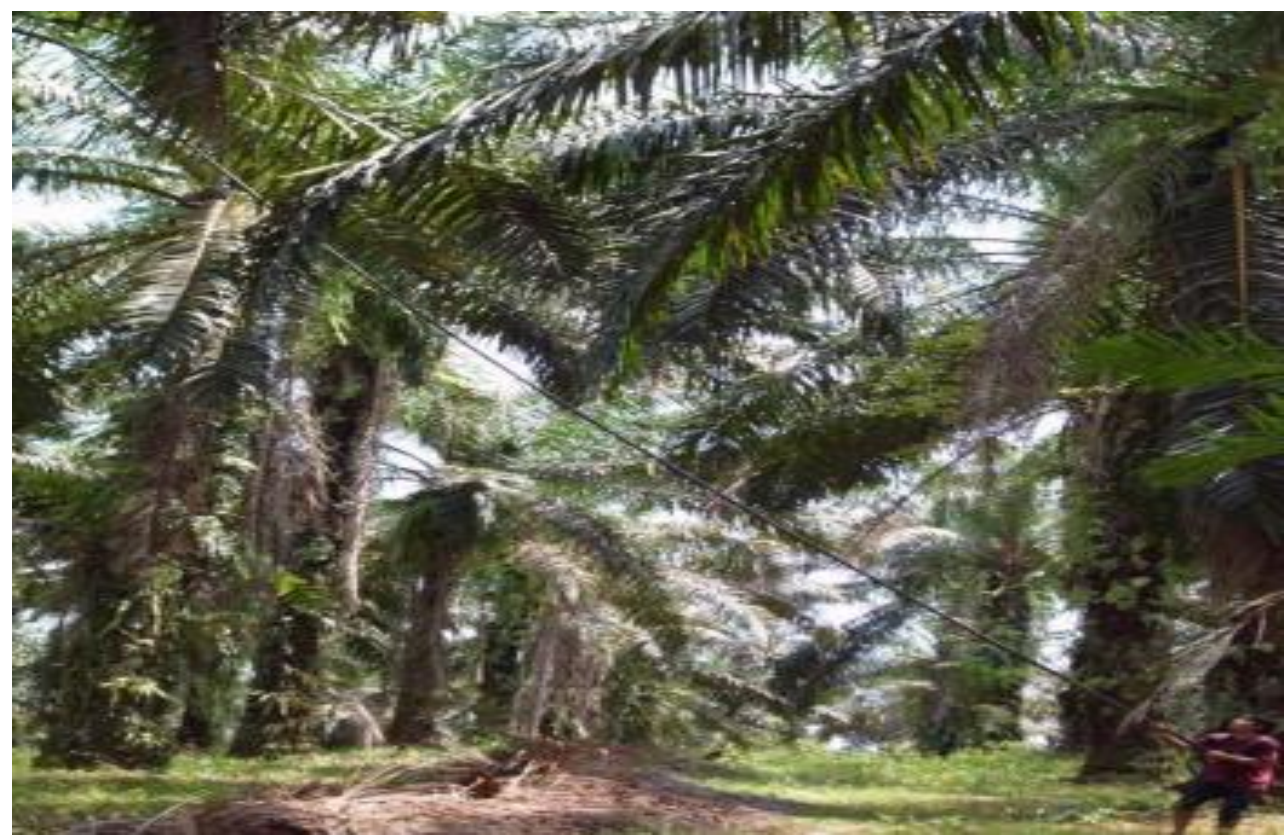

Gambar 3. Kondisi tanaman yang tidak produktif akan di repplanting.

\section{KESIMPULAN}

Kegiatan ini dilaksanakan di balai desa yang dihadiri oleh 25 orang petani termasuk kepala desa, sekretaris desa dan asosiasi petani kelapa sawit indonesia (APKASINDO). Pelaksanaan kegiatan menggunakan metode penyuluhan, sosialisasi, demonstrasi, evaluasi dan monitoring. Hasil yang teramati antara lain, antusiasme petani yang tinggi dalam mengikuti kegiatan pelatihan ini. Tanggapan petani khususnya kepala desa sangat positif dan merasa terbantu dalam memajukan desa terutama dalam kegiatan peremajaan kelapa sawit yang menjadi permasalahan utama di desa panca mulya. Dari hasil kegiatan penyuluhan ini dilakukan pengaktifan kembali kelompok tani dengan menggunakan simluhtan. Pengaktifan kembali kelompok tani merupakan syarat mutlak untuk mendapatkan bantuan dana dari pemerintah melalui BPDPKS.

\section{DAFTAR PUSTAKA}

Anonim. 2020. Peraturan Presiden Republik Indonesia Nomor 44 Tahun 2020 Tentang Sistem Sertifikasi Perkebunan Kelapa Sawit Berkelanjutan Indonesia. Perundang undangan 4: 1-22. http://www2.pom.go.id/public/hukum_perundangan/pdf/Pengamanan rokok bagi kesehatan.pdf.

Apriyanto, Mulono. 2019. Pelatihan Dan Pendampingan Pengolahan Komoditas Kelapa. Jurnal Pengabdian Dan Pemberdayaan Masyarakat 3(2): 179-83.

Apriyanto, Mulono, Muhammad Arpah, and Amd Junaidi. 2020. Analisis Kesiapan Petani Swadaya Dalam Menghadapi Rancangan Peraturan Presiden NO. 44 Tahun 2020 Tentang Pengelolaan Kelapa Sawit Berkelanjutan Ditinjau Dari Aspek Status Lahan, Legalitas Dan Sumber Bibit Di Kabupaten Indragiri Hilir. Jurnal Teknologi Pertanian 8(1): 38-48.

Apriyanto Mulono, Sutardi, Supriyadi, and Eni Harmayani. 2017. Fermentasi Biji Kakao Kering Menggunakan Saccharomycescerevisiae, Lactobacillus Lactis , Acetobacter Aceti. AGRITECH 37(3): 302-11.

Ariyanti, Mira, M. Arief Soleh, and Intan Ratna Dewi. 2019. Sosialisasi Teknik Budidaya Kelapa Sawit Berbasis Perkebunan Kelapa Sawit Berkelanjutan. Journal of Chemical Information and Modeling 53(9): 1689-99.

Dharmawan, Arya Hadi et al. 2019. Kesiapan Petani Kelapa Sawit Swadaya Dalam Implementasi ISPO: Persoalan Lingkungan Hidup, Legalitas Dan Keberlanjutan. Jurnal Ilmu Lingkungan 17(2): 304.

Fahamsyah, Ermanto. 2018. Penguatan Regulasi Sawit Berkelanjutan Indonesia. Seminar Nasional Kelapa Sawit DPW APKASINDO Prop. Riau (September).

Hutasoit, Farmelia R, Sakti Hutabarat, and Didi Muwardi. 2015. Analisis Persepsi Petani Kelapa Sawit Swadaya Bersertifikasi RSPO Dalam Menghadapi Kegiatan Peremajaan Perkebunan Kelapa Sawit Di Kecamatan UKUI Kabupaten Pelalawan. JOM Faperta UNRI 22(1).

Irianto dan Mulono Apriyanto. 2012. Analisa Mutu Minyak Kelapa Sawit Mentah DI POM IV Nyato PT. TH INDO PLANTATIONS Kecamatan Pelangiran Kabupaten Indragiri Hilir Riau. Jurnal Teknologi Pertanian 1(2): 47-56.

Iwan Inrawan Wiratmadja, Noneng Nurjanah, dan Amelia Kurniawati. 2017. Model Penerimaan Petani Terhadap Teknologi Sistem Pertanian Organik Di Kabupaten Tasikmalaya. Jurnal Manajemen Teknologi 16(1): 81-91.

Nugraheni, Endang, dan Nurmala Pangaribuan. 2008. Pengelolaan Lahan Pertanian Gambut Secara Berkelanjutan. Universitas Terbuka, Tangerang Selatan Universitas Pajajaran: 73-88. 
JPM: Jurnal Pengabdian Masyarakat

Vol 1, No 1, Juli 2020, Hal 1-6

ISSN XXXX-XXXX (Media Online)

Nurfathiyah, Pera, dan Rendra. 2013. Penyuluhan Tentang Peremajaan Kelapa Sawit Dan Kelembagaan Petani Di Kecamatan Sungai Bahar Kabupaten Muaro Jambi. Jurnal Karya Abdi Masyarakat 2009(1): 93-98.

Puspa Nandari. 2018. Dinamika Kesiapan Petani Kelapa Sawit Dalam Penerapan Indonesia Sustainable Palm Oil (Ispo) Di Provinsi Jambi Nandari Puspa. Tesis, Departemen Manajemen Fakultas Ekonomi Dan Manajemen Institut Pertanian Bogor.

Sibarani, Dewi Yosefin Tumiar, Sakti Hutabarat, and Novia Dewi. 2015. Prospek Dan Tantangan Petani Kelapa Sawit Swadaya Di Desa Air Hitam Kecamatan UKUI Kabupaten Pelalawan Dalam Menghadapi Sertifikasi ISPO. Jom Faperta 2(1): 1-9. Anonim. 2017. Luas Areal Kelapa Sawit Menurut Provinsi Di Indonesia, 2013-2017.

Zeweld, Woldegebrial, Guido Van Huylenbroeck, Girmay Tesfay dan Stijn Speelman. 2017. Smallholder Farmers’ Behavioural Intentions towards Sustainable Agricultural Practices. Journal of Environmental Management 187:71-81. http://dx.doi.org/10.1016/j.jenvman.2016.11.014 